\title{
Political Tuning in Ankara, a Capital, as Reflected in its Urban Symbols and Images ${ }^{1}$
}

\author{
AYGEN ERDENTUĞ AND BERRAK BURÇAK ${ }^{2}$
}

A recent development in the study of urban culture has been various accounts of urban symbols and images. ${ }^{3}$ The 'official' urban symbols are usually created by the elite, and the urban and national administrators, whereas the imagery is the result of the intricate interaction process between the urbanites and the country dwellers (Nas, 1993a: 5). ${ }^{4}$ Schneider defines a 'symbol' as 'something which stands for something else' (Schneider, 1980: 1). This is possible through the consensus of a group or a society on the meaning that an object conveys. Hence, 'statues, paintings, stamps ... can be considered carriers of symbols' (Nas, 1993b: 14), reflecting the values predominant in a culture. In fact, all types of cultural artefacts, including photographs, flags, constructions, even songs, and natural objects (such as hills, rivers, etc.) can be added to this list.

On the other hand, imagery consists of the mental pictures or ideas concerning the object in question and is 'linked to values derived from outside' (Nas, 1993b: 14). It is created by the 'imprint' of the objects, considered as symbols, on the people concerned. In the case of urban mediums, 'symbols and images depict or caricature a condition, a trend, a problem or an injustice' (Nas, 1993a: 3). Likewise, street names can be good indicators of the micro-political processes involved. By producing a cult of national unity that has military and political bases, as in Argentina, they can 'call our attention to an underlying civic mentality' (Van Oss, 1982: 93).

Though the case in Ankara resembles that of Argentina in such an orientation, it differs in its homage to intellectuals, foreign statespersons and their countries. Another point of divergence is the frequent renaming of these landmarks in tune with the political ideology employed by those in power, indicating the pluralism and volatility in Turkish society.

1 This paper was presented at the symposium, 'Urban Symbols and Rituals', of the IUAES Commission of Urban Anthropology at Ljubljana, Slovenia, 24-28 June 1997, under the title, 'The transformation of Ankara as reflected in urban symbols and images'. I have amended the title in keeping with the discussions on the paper. With 'political tuning', I refer to the politically motivated adjustment to a standard, or to the proper and required conditions of a cause (A. Erdentuğ).

2 Though it fell to my lot to materialize and finalize the article, it would not have been possible without the legwork of a former student doing graduate work at the department of History at Bilkent University. She also provided some of the historical information for the draft of the manuscript. I am grateful to Fuat Keyman for his helpful suggestions concerning the political background. Otherwise, I am responsible for any errors or omissions in the symbolism depicted as well as those in the analyses and conclusions drawn, including those related to Atatürk (A. Erdentuğ).

3 See Nas (1993a). There is a bibliography on this subject (Nas et al., 1997).

4 For a comprehensive list of the concepts related to urban symbolism see Nas (1993b: 15-16). 


\section{Historical background on the Ottomans, Turkey and Atatürk}

Founded in 1299, the Ottoman Empire lived its golden age under Suleiman 'The Magnificent' (1520-66), as he has come to be known in the West. The capital became 'Istanbul' (Constantinople) in 1453. At its zenith, in the sixteenth century, the borders of the empire stretched from Europe to North Africa and the Arabian peninsula, including Azerbaijan in the east. A series of external and internal factors brought it into decline. The modernization of the military was later followed by the Tanzimat (Reform) period. The reforms proved to be inadequate, against the backdrop of nationalistic insurrections up to the first world war. The Ottomans allied with Germany and found themselves at war on several fronts.

Mustafa Kemal gained instant recognition at the Gallipoli front in 1915. Even so, with the Treaty of Mudros (30 October 1918) that ended the war, the Ottoman government and army silently witnessed the occupation of Istanbul and the Empire by the Allied powers. On 19 May 1919 Mustafa Kemal arrived at Samsun, a Black Sea port, and set about the task of organizing a movement of independence. Following the meetings of members of the societies of national resistance - known as Müdafaa-i Hukuk (Defence of National Rights) - at Erzurum and Sivas, Mustafa Kemal was able to achieve national support for his cause, which culminated in the establishment of the National Assembly on 23 April 1920 in Ankara.

With the Treaty of Sèvres, 'the partition of Anatolia - the homeland of the Turks' was at stake (Heper, 1994: 66). The backlash of the nationalist government in Ankara was a series of Greco-Turkish battles resulting in the Turkish forces regaining Izmir from the Greeks; new frontiers had also been renegotiated with the Soviets and the French. The treaty of Lausanne on 24 July 1923 ratified Turkish sovereignty in the Anatolian peninsula and eastern Thrace. On 13 October 1923 Ankara became the capital, to be followed, on 29 October 1923, with the proclamation of the Republic of Turkey, with Mustafa Kemal as its first president. ${ }^{5}$ He adopted the surname Atatürk (the father/ancestor of the Turks) in 1934 and became 'Kemal Atatürk'.

In the new nation state, 'the secular-nationalist doctrine replaced Islam as the cultural foundation and overall ideology of Turkish polity'. This Kemalist secularism was not antireligious but anti-clerical (Özbudun and Kazancigil, 1981: 2, 5). It is generally accepted as a revolution from above, initiated by Atatürk and carried out by the Kemalist political elite. Atatürk was influential in replacing Islamic headgear and clothes with western wear. He was also instrumental in the adoption of the Latin alphabet and surnames, in addition to granting suffrage for women. He encouraged and adopted codes that would greatly improve the status of women in the following years, enabling them to have access to education and all professions. Turkey remains today the only secular Islamic country where the legal system is completely secularized (Özbudun and Kazancigil, 1981: 4).

Spencer (1996: 537) points out that in a given culture, symbols can become 'central points of orientation on which all else depends'. People may use currently available symbols, or create new ones, to trigger a nationwide cult, as in the case of Turkey. Over the years, Atatürk symbols (busts, statutes, portraits, photographs, excerpts from his speeches, badges etc.) have come to exist in practically every public and private enterprise in the country, even homes. The adoration of Atatürk has evolved, making him a cult-figure of 'secularism-modernity-republicanism' during the recent and ongoing 'tug-of-war' between the 'conscious Muslims' (Saktanber, 1997: 142) or the fundamentalists and the secularists in Turkey.

5 For a general background on the Ottoman Empire, Turkey and Atatürk, see Heper (1994), Inalc1k (1994), Kazancigil and Özbudun (1981), Kinross (1964; 1977), Lewis (1968), Schick and Tonak (1987), Shaw and Shaw (1976/1977). 
The emergence of this cult is a backlash against the anti-Atatürk activities that have been observed since the political party Refah ('Prosperity Party': Heper, 1997), known for having members with fundamentalist tendencies, came into power in 1996 in coalition with a right-wing party. Disparagement and vandalizing of symbols commemorating Atatürk and his reforms increased, in comparison to the odd incident in the recent past. With the determination of the military to protect the secular regime, this government had to resign. It was replaced in mid-summer of 1997 by a left-right coalition government.

On the other hand, there is a hierarchy of symbols involving the impression they leave on citizens, as being of a higher or lower order. Furthermore, symbols are associated with societal levels (Nas, 1993b). In Turkey, Atatürk symbols are of a higher order among its citizens at the national level, while those representing 'secularism' — one of his principles - have become the political manifesto of the intellectual-bureaucratic elite (Heper, 1994: 75).

\section{Ankara: its history, economy and population}

Ancyra, a settlement centrally positioned in the Anatolian peninsula, had been an important military and religious centre during the Roman and the Byzantine hegemony. It also had the character of a commercial town that gradually waned into a frontier fortress. The Ottomans had gained complete control of what became known as 'Angora' by the first quarter of the fifteenth century, turning it into an important commercial centre in agricultural products, animal husbandry and the production of the white silky wool of the Angora goat. By the seventeenth century, it had become a significant market town with its Muslim and non-Muslim inhabitants (i.e. Greeks, Armenians and Jews) populating the environs of its historic citadel (Faroqhi, 1987). The mosques, the bedestens (closed bazars) and the inns for itinerant merchants were the prominent urban symbols of the Ottoman period. The trade that existed in the town is reflected in some quarters and street names dating to this period: e.g. the quarters of Atpazarı (the horse market) and Samanpazarı (the hay market) and the streets Çıkrıkçılar (the spinners) and Saraçlar (the saddlers).

After it became Ankara, the capital of Turkey, the governments of the first two decades appointed German architects, engineers and craftsmen to plan and construct a new city to the south of the old settlement. Since the population was about 75,000 by 1927, the Jansen plan anticipated 300,000 inhabitants by the 1980s (Ana Britannica, 1987). Despite that, internal migration with its mushrooming squatter settlements took its toll in Ankara. Gradually, with political investments providing municipality services and the rise in estate values, these settlements turned into districts with modern, multistoreyed apartments. In fact, the rural and the modern exist side by side. Understandably, such 'mixed' neighbourhoods are fraught with interstrata and interethnic — since regionalism is still strong - tensions and frustrations (Erman, 1996). One outcome of this urban growth, reaching a population of about two and a half million by 1990 and more than three and a half million by the end of 1997, was the creation of the municipality of Greater Ankara.

The city has the image of being a conservative 'city of civil servants', attracting immigrants seeking job security in public offices. It lacks important industries or activities save that of bureaucracy, politicking and higher education. To date, there are four state and three private universities in Ankara. The increasing traffic forced the mayors to construct an underground transportation system to be completed by the end of this century. Some of the planned lines have been put into service, usually displacing former landmarks and changing the face of most squares. In spite of the diplomatic corps in its midst, the city falls short of the 'cosmopolitan' dimension that is characteristic of 
Istanbul and Izmir. Nonetheless, the commercial sector of the city has prospered since the 1980s, evidenced by the new shopping centres, suburban residential areas and branches of domestic and foreign upmarket chainstores and hypermarkets.

\section{The early republican period until the 1950s}

New Ankara developed rapidly to the south of the old settlement and consisted of grids of small streets cut across by two main roads: Atatürk Boulevard on the north-south axis, and Gazi Mustafa Kemal Boulevard on the east-west axis. Major buildings, public offices and some embassies were scattered mostly along the southern part of the former. At the junction of these two main streets was Kizllay (Red Crescent) square, named after the institution and its park at its north-western corner. Its vicinity was referred to as Yenişehir (new city). The west and the east were the residential areas of the republican period until the 1950s, with dwellings also along some parts of the boulevards. To the south of Kızılay, up on the hill of Çankaya, was, and still is, the presidential residence. At present, across the street, is the Prime Minister's residence next to that of the Minister of Foreign Affairs. Neighbouring them are those of the Chiefs of Staff. Accordingly, the term 'Çankaya' has come to symbolize, in political circles and the mass media, 'the seat of power'. The new embassies constructed in the southern part of the city during this period were to become landmarks of the three upper market residential and commercial districts of the city (i.e. Çankaya, Kavaklıdere and Gazi Osman Paşa ${ }^{6}$ ), as well as demarcating the zone to be inhabited by the diplomatic corps and other foreigners.

In the ensuing two decades after the proclamation of the republic, some of the names ${ }^{7}$ given to boulevards, streets, city squares and residential quarters were commemorative of Atatürk (e.g. Selanik ${ }^{8}$ street) or the heroic deeds in the War of Independence (e.g. Milli Müdafaa (national defence) and Izmir main streets; Kocatepe ${ }^{9}$ quarters and Lozan (Lausanne) square. Others were named after the military (e.g. Fevzi Çakmak ${ }^{10}$ street); statespersons (e.g. Saraçoğlu ${ }^{11}$ quarters); local administrators (e.g. Tandoğan ${ }^{12}$ square) and poets or authors (e.g. Ataç ${ }^{13}$ street). Another trend was to give the names of the main rivers of Turkey or those of flowers. Names of the old civilizations of the Near East (e.g. Sümer or Sumerian street) were reflective of the Anatolian movement ${ }^{14}$ of the $1930 \mathrm{~s}$ initiated by Atatürk. In some residential areas they fell short of names and started numbering the streets. During this period, the fad at Anafartalar ${ }^{15}$ 'high street' was to put the word Asri (modern) in front of traditional terms, e.g. Asri Bakkaliye (modern grocer), Asri Pastahane (modern patisserie) etc., including the new public WC!

6 The first two are indigenous names. The last is a famous Ottoman general (1832-1900). His defence of Plevne along the Danube against the Russians was so incredible that it became the theme of a song that gained popularity during the student demonstrations in 1960 and in 1968.

7 Biographical information on the people mentioned henceforth has been compiled from Büyük Larousse (1992) and Ana Britannica (1987).

8 Salonika or Thessaloniki (Greece) where he was born when the territory was under Ottoman rule.

9 A hill that became famous with the battle of Dumlupinar, in western Anatolia.

10 Fevzi Çakmak (1876-1950) was a prominent commander during the War of Independence and later a statesperson. He was also the first Chief of Staff of the republic.

11 Sükrü Saraçoǧlu (1887-1953) was a politician and a statesperson who held office as Prime Minister from 1942-46, and later as Speaker of the Grand National Assembly for two terms.

12 Nevzat Tandoğan (1894-1946) was the Governer of Ankara during 1929-46. There is also a street named after him.

13 Nurullah Ataç (1889-1957) was a popular critic and the translator of over 50 books. He also promoted the usage of pure Turkish and became a leading member of a new wave in Turkish poetry.

14 The Anatolian movement supported the thesis that the Turks, through waves of migration from Central Asia, had generated the Chinese, Indian and Middle Eastern civilizations. The movement came to an end with the death of Atatürk in 1938, since major supporters abandoned the cause (see Lewis, 1968: 358-60).

15 The famous battle hills of the Gallipoli front. 
The monuments or statues in Ankara ${ }^{16}$ of this period were commissioned to foreign sculptors. The statues were of Atatürk, carrying a stern expression and in military costume. The one in downtown Zafer (victory) square showed him in his general's uniform, standing, leaning over his sword and looking ahead, as he was wont to do. Another, an equestrian Atatürk, was placed in front of the newly constructed Ethnographical Museum ${ }^{17}$ on a hill overlooking the expanding Ankara. The pedestal of this statue is a rectangular prism of red marble with small low reliefs ${ }^{18}$ on two sides. One shows Ankara in ruins but with a sun shinning on it. The other is a post-battlefield scene. There are also small round low reliefs on the remaining sides depicting scenes from behind the battle fronts and one showing the downfallen Sultan leaving the country.

The first large monument during this period, in Ankara, is the Cumhuriyet (republic) monument at Ulus (nation) ${ }^{19}$ square, the latter giving its name to the district. It consists of a stone rectangular prism with middle reliefs on its left and right faces depicting scenes from the War of Independence. One of them is a scene showing Atatürk giving the famous battle order 'Soldiers, your goal is the Mediterranean'. The structure functions as a base pedestal for the statue of Atatürk, in military outfit, and on horseback, which is mounted on another wider pedestal (there had also been a third one $e^{20}$ on the ground, with the heads of two wolves ${ }^{21}$ sticking out from its front part and facing opposite directions as if keeping watch). On either side of the main structure is a statue of a Turkish soldier in combat. At the back of the structure, facing the citadel, is another statue of a peasant woman carrying a cannon ball on her back, for lack of transport, to the battle fields. The monument was, until the Mausoleum, the unofficial symbol of Ankara and the venue of national ceremonies.

The Güvenlik (security/police) monument, in a park at the southwestern corner of Kizilay square, has two faces. Erected in 1935, it suggests the road to prosperity and power. On the southern face there is a high relief of Atatürk, putting out a bent arm in self-protection. He is flanked by four men, two on each side. The pair on his right have joined hands, while the other two are ready to draw their swords. The group symbolizes unity and readiness to challenge the enemy. Down below, at ground level, on both sides of this relief, are two further groups of high reliefs. The one on the left depicts the farmworkers in the field while the one on the right shows craftsmen at work. On the northern face, the ground reliefs continue, showing other working men and women. Above them are two bronze, giant size muscular men: One of them is old - representing the ancestors - and has a stack of sticks, symbolizing 'protection', in his hand that he is about to lay down. The other is young — the youth — and he has a similar stack in his

16 Ankara has about a hundred monuments and large or small statues. Some of the information on these have been compiled from Börtücene (1993), Özel (1991) and Batur (1994).

17 After his death on 10 November 1938 and ceremonies of reverence until 19 November 1938, the embalmed body of Atatürk was buried, temporarily, at this Museum until his remains were transferred to the Mausoleum in 1953 (for more details on this event, the Mausoleum and its photographs, see Meeker, 1997: 168-75).

18 For those not familiar with sculpture terms: 'low relief' is a representation of figures raised upon a flat surface without any part of them being entirely detached from the background, as in a medal. 'High relief' is that in which the figures project at least one half of their apparent circumference from the background. 'Middle reliefs' are somewhere between the two.

19 Formerly it was known as the Taşhan (stone inn) square. It became a meeting centre during the War of Independence, since the building used as the first Grand National Assembly was within a stone's throw. With the opening of the monument in 1927, the square was renamed Hakimiyet-i Milliye (national sovereignty), but with the pure Turkish movement, changed to Ulus.

20 With the reorganization of the square in 1959-60, the monument was moved some distance to its left and the third pedestal was discarded.

21 They symbolize 'Ergenekon', a Turkish myth dating back to Central Asia. There are various versions of it. The main theme is that the Turks could not have found their way out of where they had hidden and multiplied, i.e. in Ergenekon, were it not for the guidance of a grey wolf. The wolf later became the symbol of extremely nationalist militia. 
arms that he is about to put on his shoulder, indicating that he has taken over. Underneath them, in bold letters, is a dictum by Atatürk: Türk Öğün Çalış Güven (Turk! Be proud, work and be confident).

\section{The 1950s and 1960s}

The most majestic monument of modern Turkey, the 'Mausoleum of Atatürk' takes up an area of 15,000 square meters. Designed by two Turkish architects and constructed between 1944 and 1953, the travertine construction situated on Anittepe (monument hill) displays Turkish sentiments about independence. A flight of stairs leads to the entrance, at either side of which are two towers: Istiklal (independence) to the right, and Hürriyet (liberation) to the left. In the immediate vicinity of these towers are giant size statues of three men (on the left) and three women (on the right), representing the Turkish nation. The entrance leads to a long alley, known as Arslanli Yol (the road with lions), decorated on either side with twelve huge, twin Hittite lions. The alley ends with two more towers, Mehmetçik $^{22}$ and Müdafaa-i Hukuk (defence of national rights), opening on to Zafer (victory) square $(80 \mathrm{~m} \times 130 \mathrm{~m})$, producing a T-shaped layout. There are two more towers, 23 April $^{23}$ and Misak-i Milli (national pact) exactly opposite them, across the square, flanking the stairs to the garden. At each corner of the Zafer square are the towers Zafer, Barış (peace), Inkilap (reform) and Cumhuriyet (republic).

In the hall between the 'National Pact' and 'Victory' towers is the Atatürk museum, displaying his personal belongings, medals, gifts from heads of state and so on. Next to it, between the 'Victory' and 'Peace' towers, to the right of the square from the alley, is the grave of Ismet Inonü, Atatürk's comrade-at-arms and the President after his death.

Just across from this grave, in a protruding rectangular annex to the left of and thirtythree steps ${ }^{24}$ up this square, is Atatürk's place of eternal rest. On both sides of the stairs are middle reliefs depicting scenes from the War of Independence, commissioned to Turkish sculptors. The exterior of the wall to the left of the entrance to the hall at the top of these stairs, known as Şeref Salonu (hall of honour), is covered with a carved out giantsize copy of Atatürk's famous address to the Turkish youth. Likewise, to the right of this entrance, is an excerpt from his famous 'Speech of the Tenth Year' (i.e. of the Republic). The walls and floor of the interior are of marble, while the ceiling is overlaid with golden mosaic tiles. Across the entrance to this hall, in front of the large window overlooking the citadel of Ankara, is a sarcophagus carved out of a block of marble, symbolically representing his eternal 'abode'. His remains are buried deep down beneath it, together with earth from various regions of Turkey, in a grave that is closed to the public. Only recently has the nation been allowed a first, brief glimpse of his grave via a Turkish TV channel and photographs in a national newspaper.

In the face of the fundamentalist threat and the 'dissident' activities of PKK - a Kurdish terrorist group active in south-eastern Turkey - the Mausoleum has become a sort of 'Wailing Wall'. People of all professions and lay-persons have started coming in endless throngs to commemorate Atatürk and reproach those working against secularism, the republic and modernization of the country. It is also frequently visited by secularist non-governmental women's organizations, denouncing all fundamentalist directives designed to place them in an inferior position. Such activities indicate that the Mausoleum

22 The endearing colloquial expression for the Turkish soldier. It is usually used with the epithet arslan (lion), referring to the 'lion-heartedness' of the Turkish soldiers.

23 The date the first Grand National Assembly met at Angora (23 April 1920). The date has since become 'The National Sovereignty and Children's Holiday'.

24 Reminding one of the compulsory number of 33 (or 99) beads on the rosary used by Muslims during prayers. 
has evolved into a Kemalist site representing nationalism, modernity and the state (Meeker, 1997: 157).

By the 1950s, Turkish sculptors had started to turn their attentions elsewhere, as exemplified by the white marble statue of Mimar $\operatorname{Sinan}^{25}$ in the front garden of the Faculty of Letters, History and Geography in Sihhiye. Another one, that of Mithat Paşa, ${ }^{26}$ had also been placed by this time in the front garden of the Ziraat (agriculture) Bank in Ulus. Even so, there was to be an interval in the unveiling of monuments and statues until the 1980s.

The 1950s witnessed the passage from domination by a statist elite to a multiparty system, which enabled the emergence of parties representing and articulating the interests of the people (Heper, 1994: 75). This triggered a set of long-ranging changes and political instability in the country, to a degree that caused the decade to be referred to as a watershed (Stirling, 1974). In the meantime, Ankara had started to expand beyond its envisaged capacity. Some of the new neighbourhoods were named after political events of this period (e.g. 14 May1s ${ }^{27}$ Evleri). With the coup d'état of 1960 in Turkey, the junta (i.e. the The National Unity Committee) went to great pains to honour more statespersons, heroes and heroines (e.g. Nene Hatun ${ }^{28}$ and Tunalı Hilmi ${ }^{29}$ streets) related to our past. They went as far as to rename the main city square of Kizılay as Hürriyet (liberation) square. The old name was later restored.

By the 1960s, the custom of naming a street in the Çankaya-Kavaklidere-Gazi Osman Paşa triangle, usually after a country or its political leader, in memory of an important state visit or the death of political allies (e.g. Jan F. Kenedi - John F. Kennedy - street) had become established. It continues to this day.

This period was also marked by an unanticipated increase in horizontal social mobility, due to multiple factors explained in detail by Stirling (1974). This meant an increase in the mushrooming squatter settlements on the periphery of Ankara. Squatter settlements had existed since the 1940s, on Treasury land, first, to the north, and on the steep hills around and across 'old Ankara'. They gradually made their way to the east of the city, finally encircling it by the 1980s. 'The outcome, among other things, was relative ruralization of the urban scene, retraditionalization of social life, and occasional displays of fundamentalist tendencies' (Heper, 1994: 75).

\section{From the 1970s to the present}

As in other cities, the squatters in Ankara were to provide an important pool of voters, forcing the competing political parties to adapt more short-term populist policies and to politicize religion. The left-right clash and political violence permeated society and reigned throughout the cities during the 1970 s, culminating in the second coup d'état of 12 September 1980 . By this time, the military had recognized religion as a crucial element in social unity and even tolerated its politicization, provided it 'did not border on fundamentalism' (Heper, 1994: 76).

25 He was a famous architect (1489/1490-1588) of the Ottoman period who has over three hundred works to his name.

26 Mithat Paşa (1822-84) was an important figure of the Reform (Tanzimat) period (1839-76) of the Ottoman Empire. He was influential and instrumental in the emergence and the continuation of a credit system for the agriculturalists.

2714 May 1950 is the date of the general election in which the Democrat Party had a landslide victory, putting an end to the monoparty system. Their policies led to enormous deficits, inflation and anti-secular activities (Heper, 1994: 67). The military intervened on 27 May 1960 to prevent a possible civil war. With its downfall, the junta renamed this quarter 'Gazi Osman Paşa'.

28 Nene Hatun (1857-1955) was an active female member of the militia in Erzurum against the Russians in the Turko-Russian War of 1877-78.

29 Tunalı Hilmi (1871-1928) was a statesperson and an author who had been a prominent figure in the Young Turks and in the Pan-Turkism movements. 
Parallel to the political ideology of local administrators, the streets were named and renamed in memory of those who fell victim to terrorism on either side of the left-right skirmishes. This custom has been carried on to this day to include victims of fundamentalist terrorism. The most prominent ones to date have been Abdi Ipekçi park, Bedrettin Cömert, Bahriye Üçok and Uğur Mumcu streets and Çetin Emeç ${ }^{30}$ boulevard.

In retrospect, it has fallen more to the lot of the mayors of left-wing parties to promote an interest in the regeneration of the city. Prior to their intervention the diplomatic corps considered Ankara a zone of deprivation. To give them their due, a few right-wing mayors were also instrumental in this regeneration. Each mayor had his own obsession with making Ankara 'modern'. One promoted roundabouts at junctions to ease the traffic. Another was fascinated with the infrastructure. Others encouraged and started-off housing projects in the suburbs of Ankara, implemented natural gas heating — putting an end to the infamous smog of Ankara - and introduced schemes for new paved areas, pedestrian and green zones - ideas that they imported from their official trips to Europe.

The 1980s, after the coup d'état, was the second period in which Ankara was bombarded with monuments and statues. Atatürk was once again the main figure in a series of monuments but his image was more 'fatherly' this time. Though they have a more civilian air about them, they continue to imply national unity or the Reforms of Atatürk, in an attempt to pull together a nation torn apart by the internal strife and terrorism of the past decade.

The series begins with the Atatürk Monument, placed in a courtyard of the Turkish Grand National Assembly ${ }^{31}$ in 1981, which portrays Atatürk in civilian clothes and a man and a woman standing behind him with their backs to each other, facing opposite directions. The man is carrying a flapping flag while the woman carries a torch. ${ }^{32}$ The torch motif is repeated again, in the Başögretmen (headmaster) ${ }^{33}$ Atatürk Monument erected in front of the Ministry of Education in 1981. It is on a torch-like pedestal. In the place of the flame is an open book with a torch placed in the opening - the logo of the Ministry - symbolizing the illumination to be had through education. On the left-hand corner of the left page is a high relief of four students, with faces turned to the page on the right. On the right page, Atatürk, with head and shoulders protruding from the top of the page, is holding the torch in the opening. At his right are a young man and woman, representing the educated and the teachers, while those on his left depict the peasant man and woman.

The most majestic high relief that epitomizes Atatürk, 'Atatürk ve Harbiyeli' (Atatürk and the cadet) is unknown by the majority of the public. Completed in seven years by a Turkish sculptor, it was placed in 1988 at the entrance of a main building at the Military Academy in Ankara. It is about four stories high and in the form of a sword in its sheath standing upside down on its handle. The handle part is strewn with scenes from Atatürk's life. The outstanding part is on top of this: Atatürk, in his military uniform, is standing on a surface jutting out. Standing just behind him are those second in command. Behind them is a high relief of rows of soldiers in battle gear with the soldiers getting smaller towards the end of the rows and the tip of the sword, giving the relief a depth. An educated guess about their number would be a thousand. Against the backdrop of the

30 Abdi Ipekçi (1929-79), Uğur Mumcu (1942-93) and Çetin Emeç (1935-90) were distinguished journalists; Bedrettin Cömert (1940-78) was an art historian and Bahriye Üçok (1919-90) was a female academic and ex-parliamentarian.

31 The second colossal and monumental construction in Ankara that opened in 1960.

32 It connotes the popular depiction of the Turkish republic as a young woman draped in the Turkish flag and holding the torch, implying a bright future, hope and freedom. A man is always the flag bearer, due to the connotation of fighting and defending the flag to death.

33 Another of his epithets. One famous photograph shows him teaching his people the new Latin alphabet. 
heads of these soldiers, toward the top of the relief, is a mask of Atatürk. The message is clear: the relief implies the infinite number of his followers.

On the other hand, we also see representations of the police and the peasants on their own. Some of the statues erected were reminiscent of old Ankara, like the Angora goats or the Seymenler (the Seymens) ${ }^{34}$ — also the name of the park in which they were placed in 1983. At about the same time, two large statues depicting ballerinas dancing around a tree figure resembling a maypole was put at a corner of the junction at Kavaklidere.

A piece of modern art, outstanding in size and theme, was erected in 1981 in Abdi Ipekçi park. The statue takes the form of a pair of huge dark hands coming up from the ground and visible from the wrist up. The hands are half crossed, with the fingers and the palms facing upwards. The bonded position of the hands symbolizes the helplessness and the plight of the Turkish workers at the mercy of the industrialists.

The public was able to identify with these themes because of their level of education and cognition. The majority of the population continue to be graduates of a compulsory five-year primary school education, which has just been extended to eight years. Besides those in the arts trade, the intelligentsia and, usually, the social democrat student groups, abstract sculptures are alien to the increasingly ruralized Ankarites who are also intolerant to nudity in artefacts.

A debate over a 'semi-abstract' statue at Altın (Golden) park, in a conservative northern district, is a case in point. This metal work represented a woman sitting on a man's lap, facing him, allegedly, in an 'intimate' position. After the Prosperity Party candidate took over the office of the Mayor of Greater Ankara from his left-wing predecessor, it caused an exchange of derogatory remarks between him and the sculptor and his supporters, in addition to extensive coverage in the secularist mass media. Needless to say, it was 'liquidated' in time.

The city owes all efforts to unite the Ankarites around a city symbol to the left-wing mayors. The first emblem introduced was the Hitit Güneşi (Hitite sun): it is a 'sun disk' related to the sun cult, believed to have existed among the Hittites; the disks were displayed on rods during their ceremonies. Two versions exist. Both have circular outer frames but differ in the designs in the centre. One of them is a lattice-cum-grid structure with a circular frame. In the other, there is a main deer figure flanked by bulls; the animals are standing on a perch that joins with a circular frame passing over their heads. The former is more popular, easily recognized and promoted. It became the logo of the municipality. A giant size bronze copy of the latter version of this artefact was placed in 1975 on a roundabout in downtown Lozan square, meeting those who took the road from Esenboğa, the airport. The statue was criticized for not taking the settlement in the region as the first Turkish inhabitation.

Just as people had become accustomed to it, another one was introduced as a response to these criticisms. This was Anki, the lovable white Angora goat, with an 'ANKARAANGORA-ANCYRA' inscription encircling it. It was met with a mixture of amusement and acceptance. Goat statues were scattered over the green areas surrounding the flyovers all over the town, and even placed beside the bushes in some parks.

The winds started to blow from the opposite direction when, with the unexpected election results of 1994, the candidate of the religious Prosperity Party became the Mayor of Greater Ankara. The party came to power with only twenty odd percent of the votes, the majority from the still heavily rural and frustrated squatter settlements undergoing culture shock.

The new mayor announced another official emblem, ${ }^{35}$ causing heated discussions in the mass media. This time it was a white silhouette against a navy blue background. The

34 The term seymen denotes bravery and manly spirit, besides an equestrian person. However, today, they have become folkloric figures.

35 We were unable to provide any illustrations of the city emblems due to the technicalities involved in clearing copyright permission. 
upper part of this silhouette consists of a mosque with two minarets, with three small stars in the sky between them. The dome of the mosque overlaps with the cap of a mushroomlike figure that represents Atakule (Ata tower) - 'Ata' being another term connoting Atatürk - with a large star at the base of its stem. The minarets bend slightly toward each other in the lower part of the silhouette, forming a crescent around this star. The tower is pale sky-blue with fine details enhancing it and bringing the structure to the forefront. The mosque is not only reminiscent of 'old Ankara', the Islamic-Ottoman past, but also of the recently completed Kocatepe mosque, the largest one built in Ankara in the republican period. ${ }^{36}$ The crescent and star represent the Turkish flag. Similar to the post-office towers of some western countries, the tower is in 'new Ankara', up on Çankaya, and visible from most of the city.

New Islamic objects d'art, using Ottoman-period designs on the tiles, and forming fountains and sometimes giant replicas of coffee cups and saucers, tea pots etc. - like those in the 'Mad Hatter's Tea Party' section in Disneyland - have been introduced in the municipalities under their control. The Prosperity Party's obsession with decorating Ankara with water fountains of all sizes has revitalized a feature of Islamic and Ottoman architecture.

Similarly, the new tendency in renaming streets has shifted toward honouring Islamic countries and the Turkish republics. Two streets in Kavaklidere have been changed to Kuveyt (Kuwait) and Abay Kunanbay (a Chechen leader). The attitude of residents to the renaming of their streets is usually one of resignation. So the opposition shown to this Prosperity Party 'tuning' is more of a political statement than an identification with the old name. Even when the mayor opted to rename streets in another established district that had formerly been denoted by numbers, as Taşkent, Bişkek, Aşkabat and Kazakistan, he was again criticized severely.

On the other hand, the 'westernized' part of Ankara, i.e. the Çankaya-KavaklidereGazi Osman Paşa triangle, continues to be under the domain of a left-wing municipality, so that it still maintains its overall image. Western-design arcades, shopping malls and catering places with western-style refurbishment abound. A striking aspect of these commercial-cum-residential and affluent districts is that most of the shops and catering firms insist on having western names; a considerable number of them are branches of international chains. Even the local small grocery shops have become 'markets'. The argument of the proprietors is that it is purely commercial, reflecting the preferences of their customers. The same reason is given for their Christmas ${ }^{37}$ window decorations in the last two weeks of the year, which mirror the displays in western capitals. By contrast, in municipalities turned over to the Prosperity Party, all forms of new year decorations, celebrations, the selling of alcohol and even the New Year's Eve turkey have been outlawed this past season (1996), on the grounds that it is a Christian festivity.

\section{Discussion and conclusions}

In the span of seventy odd years, three considerations have been effective in Ankara: homage to Atatürk; modernization via westernization; and Turkish-Islamic, if not fundamentalist, tendencies, as represented by the Prosperity Party.

The War of Independence had provided the country with a national hero and leader who was revered by the nation, even by those who did not comprehend his reforms. The 'ancestor worship' and his image mellowed with time. From a stern military hero and

36 Meeker, quite aptly, sees this mosque - in open view of the Mausoleum and in 'a relationship of challenge and response' to it - as an Islamist site representing religion, tradition and society (Meeker, 1997: 157).

37 See the article (in Turkish) (Erdentug, 1987) on the diffusion of the Christmas tree and decorations into the culture of Ankara. 
leader, he eveolved into a civilian and a 'father' figure to turn to in times of crises. In the face of dissident or fundamentalist threats he has come to symbolize national unity, secularism and modernization. He is now a national idol, reflected in an increase in the number and variety of Atatürk symbols.

In addition, there have been modernizing forces in Ankara that have gradually transformed it into a thriving commercial and educational centre. It has had two main stimulants: the eagerness for acceptance into the European Union; and, through 'Socialist International' connections, an anxiety about egalitarianism and equal opportunity. The right-wing Motherland party, in support of integration into Europe, introduced a set of measures and incentives for economic institutions that promoted export-import. This eventually increased the consumption and demand of the middle class and, partially, that of the lower economic class, besides creating the 'new rich'. At one point, the party even resorted to a populist policy, encouraging the migrants to gain title to the land on which they had squatted. In contrast, the socialist parties, adopting more egalitarian populist policies, preferred to accommodate and later assimilate the squatter settlements. These developments gave the squatters the expectation of an exchange, with a contractor, of the titles to their plots in return for modern flats. However, unemployment has steadily risen, mostly due to lack of qualifications and the preference for job security within the public sector.

The aftermath of such modernization efforts has been the addiction, of most Turks, to symbols considered 'western', affecting commerce, status symbols and the image of Ankara. The independent TV channels, with their films and endless commercial advertisements leading to a consumption boom, have supported 'the Western way'. Consequently, the efforts to seem 'westernized', regardless of the values involved, are considered to be part of the process of becoming 'modern'. Yet, Ansari specifically draws attention to the difference between modernization and westernization: the former is ' $\mathrm{a}$ stage in socio-economic advancement which transforms age-old patterns of social interaction and economic structure into new forms'; whereas the latter 'is a cultural trend in which people of the East look admiringly towards nations of the West as their ideals in all areas of life' (Ansari, 1980: 28).

The people in the squatter areas have not escaped the demonstration effect of western affluence either. They too yearn for the comforts they have witnessed and 'implant' them to their modest houses. Relatives or fellow villagers who are migrant workers in European cities have also acted as culture brokers. 'The consequence was a bifurcated society of cognitively Westernized elites who despised people's 'traditional' values and people also cognitively Westernized yet clinging to their Moslem and other communitarian values' (Heper, 1994: 75). The end product was a city that underwent a 'face lift', as symbolized by various cultural borrowings from the West. Some groups thrived on western brands and led a hedonistic existence. New TV channels freely interpreted their 'independence' and enraged the conservatives with unsuitable programs, to the degree that channels 'for the family' came into existence.

This rapid change and the shallowness of such developments made some groups uneasy, since the diffusion of material culture eventually carried over certain values that were at odds with the indigenous ones. The backlash was a demand for the Islamic way of life. Ironically, the Atatürk reform of secularism became the scapegoat, taking the blame for this unforeseen westernization. In a very short time, Turkey was drawn into a polarization of 'secularists', and 'conscious Muslims' — since, with the exception of a negligible percentage of non-Muslims, all of the citizens are Muslims. The latter category insists on creating its own middle class with a separate economy, education, mass media, entertainment, fashion, amenities, 'urban complexes' (Saktanber, 1997: 144-7), hotels etc.

For the Prosperity Party supporters, Islamic symbols are of a higher order, maintaining social control. The women are in tesettür (covered). The supporters range 
from the orthodox to the liberal or reformist in their attitude to Islam. It is the latter group that is economically better off and more exposed to modernization. The women in this group have higher education, drive cars and are gradually entering the mainstream in all professions, in spite of their attire being banned in public offices. ${ }^{38}$ In fact, this group utilizes all the amenities and equipment that modern technology offers at home and in the office, contributing to the demand for modern symbols in the city. However, they identify themselves with the Ottoman past and Islam. Some are, allegedly, oriented to Islam in Saudi Arabia or Iran. Whatever their true motives may be, it is a fact that they are here to stay and, 'God willing', will continue to make Ankara a modern but not westernized Islamic capital! ${ }^{39}$

Aygen Erdentuğ (erdentug@bilkent.edu.tr), Department of Political Science and Berrak Burçak (berrak@bilkent.edu.tr), Department of History, Faculty of Economics, Administrative and Social Sciences, Bilkent University, Bilkent 06533, Ankara, Turkey.

\section{References}

Ana Britannica (1987) Ana Yayıncılık ve Sanat Ürünleri Pazarlama, Istanbul.

Ansari, G. (1980) Modernization versus westernization: an Islamic viewpoint. In Proceedings of the Symposium, Islam and a New International Order: The Social Dimension, International Institute of Labor Studies of the ILO, Geneva.

Batur, E. (ed.) (1994) Ankara Ankara. Yapı Kredi Bank, Istanbul.

Börtücene, D. (ed.) (1993) Bir zamanlar Ankara [...] [Once upon a time, Ankara[...]]. Pan Ofset, Ankara.

Büyük Larousse (1992) Milliyet Gazetıcilik A.Ş., Istanbul.

Erdentuğ, A. (1987) Yılbaşı ağacı ve Noel baba: Türkiye'de bir kültürel alıntı örneği [The Christmas tree and Santa Claus: a case of cultural borrowing in Turkey]. Belleten (T.T.K.) $51.200,863-95$.

Erman, T. (1996) Experiences of Turkish migrant women in squatter (gecekondu) and apartment housing. Environment and Behaviour 28.6, 764-98.

Faroqhi, S. (1987) Men of modest substance: house owners and house property in seventeenthcentury Ankara and Kayseri. Cambridge University Press, Cambridge.

Heper, M. (1994) Historical dictionary of Turkey. The Scarecrow Press, Metuchen, New Jersey. (1997) Islam and democracy in Turkey: toward a reconciliation? The Middle East Journal $51.1,32-45$.

Inalcik, H. (1994) The Ottoman empire: the classical age (1300-1600). Phoenix, London.

Kinross, J.P. (1964) Atatürk: the rebirth of a nation. Weidenfeld \& Nicolson, London. (1977) The Ottoman centuries: the rise and fall of the Turkish empire. Morrow Quill Paperbacks, New York.

Lewis, B. (1968) The emergence of modern Turkey. (2nd edn.) Oxford University Press, London.

Meeker, M.E. (1997) Once there was, once there wasn't: national monuments and interpersonal exchange. In S. Bozdoğan and R. Kasaba (eds.), Rethinking modernity and national identity in Turkey, University of Washington Press, Seattle.

Nas, P.J.M. (1993a) Introduction. In P.J.M. Nas (ed.), Urban symbolism, E.J. Brill, Leiden. (1993b) Jakarta, city full of symbols: an essay in symbolic ecology. In P.J.M. Nas (ed.), Urban symbolism, E.J. Brill, Leiden.

38 Laws and regulations concerning the attire of civil servants prohibit women from being in tesettür (covered); they are to wear modest western clothes, with the head uncovered.

39 Just after this article was submitted to the editor, the Constitutional Court closed down the Prosperity Party in January 1998. Before the ruling came into effect, some of the party members hastily formed the Virtue (Fazilet) Party. Later, with the exception of a few who were banned from politics for a couple of years, the majority of the Prosperity Party members transferred to the Virtue Party, continuing to challenge the 'Kemalists'. However, in March 1998, the military 'showed its teeth' by cajoling the coalition government to take serious circumscribing measures against the Islamists. 
A. Roymans and A-M. Harzevoort (1997) Bibliography on urban symbols and rituals. Newsletter 8 of the IUAES Commission on Urban Anthropology (April), 12-16.

Özbudun, E. and A. Kazancigil (1981) Introduction. In A. Kazancigil and E. Özbudun (eds.), Atatür: founder of a modern state, C. Hurst \& Company, London.

Özel, M. (ed.) (1991) Ankara. Ajans-Türk Matbaacılık Sanayii A.Ş., Ankara.

Saktanber, A. (1997) Formation of a middle-class ethos and its quotidian: revitalizing Islam in urban Turkey. In A. Öncü and P. Weyland (eds.), Space, culture and power, Zed Books, London.

Schneider, D. (1980) American kinship: a cultural account. (2n edn.) University of Chicago Press, Chicago.

Shaw, S. and E. Kural Shaw (1976/1977) History of the Ottoman empire and modern Turkey. Cambridge University Press, Cambridge.

Shick, I.C. and E. Ahmet Tonak (eds.) (1987) Turkey in transition. Oxford University Press, New York.

Spencer, J. (1996) Symbolic anthropology. In A.B. and J. Spencer (eds.), Encyclopedia of social and cultural anthropology, Routledge, London.

Stirling, P. (1974) Cause, knowledge and change: Turkish village revisited. In J. Davis (ed.), Choice and change: essays in honour of Lucy Mair, Humanities Press, New York.

Van Oss, A.C. (1982) Street names in Argentina and the cult of national unity. In R. Buve and J. Lechner (eds.), Latijns Amerika Studies in Leiden 1982, Rijksuniversiteit, Leiden. 